\title{
THE ROLE OF BHABINKAMTIBMAS (NEIGHBORHOOD/VILLAGE POLICE NCOS) AND COMMUNITY EMPOWERMENT IN EAST BANJARMASIN: THE ANALYSIS OF CONSTRAINTS AND COMMUNITY DEVELOPMENT
}

\author{
Haris ${ }^{1}$, Ahmad Alim Bachri ${ }^{1}$, Muhammad Riduansyah Syafari ${ }^{1}$ \\ 1, Universitas Lambung Mangkurat, Indoensia.
}

Article Info

Accepted: 2 April 2021

Published: 9 April 2021

Keywords:
Police
Bhabinkamtibmas
Community empowerment
Constraints
Comunity Development

\section{Copyright and License:}

Authors retain copyright and grant the journal right of first publication with the work simultaneously licensed under a Creative Commons Attribution 4.0 International License that allows others to share the work with an acknowledgment of the work's authorship and initial publication in this journal.

\begin{abstract}
The National Police of the Republic of Indonesia, in this case, Bhabinkamtibmas (Neighborhood/Village Police NCOs), as the leader in creating Harkamtibmas or the maintenance of security and public order in villages/sub-districts, can carry out their duties by applying the community empowerment as an effective way to involve the community in achieving all goals and hopes of creating a safe and orderly situation where they are being assigned. This had been stated in the Regulation of the Chief of the Indonesian National Police Number 3 of 2015 article 27 that the main task of Bhabinkamtibmas is to conduct community development, early detection, and mediation/negotiation to create conducive conditions in the village/sub-district. In regards to community policing in Article 1 Paragraph 2, community policing, from now on abbreviated as Polmas, is an activity to invite the public through a partnership between members of the National Police and the community, so that they can detect and identify problems of security and public order (Kamtibmas) in their environment and resolve them. The results of the research showed that community empowerment in East Banjarmasin could be carried out through the role of Bhabinkamtibmas. However, it was not optimal because many programs or activities executed by Bhabinkamtibmas were reserved to fulfilling tasks that had been assigned to them. The community empowerment was followed through practically and was limited to how to take advantage of the situation and part of the community's potential in order to finish the target assigned to them hence the role of Bhabinkamtibmas as the leader in community empowerment could not be implemented properly and sustainably. The achievement could be done through the provision of knowledge and training and education on understanding the definition of community empowerment as a process and as a goal, stages of empowerment, empowerment strategies and so on, in order to create a community in which they are ready to be efficient and independent towards creating a conducive security and public order therefore they can create a safe, peaceful community and ensure the implementation of development towards prosperity.
\end{abstract}$$
\text { (c) (†) (?) }
$$ 


\section{INTRODUCTION}

The National Police of the Republic of Indonesia or abbreviated as POLRI is a large organization that has work units in the implementation of its main tasks and functions, both Operational and Development, starting from the POLRI Headquarters, POLDA or Regional Police, POLRES or Departmental Police and POLSEK or Sectoral Police levels. The Directorate of Community Development (DITBINMAS) is one of the work units at the POLDA level that carries out its duties as a Community Guidance Supervisor as well as Operational Implementer, at the POLRES level it is called a Community Development Unit (SATBINMAS) and at the POLSEK level, it is called a Community Development Unit (UNITBINMAS) where BHABINKAMTIBMAS or Neighborhood/Village Police NCOs are the leader of community development. BHABINKAMTIBMAS which stands for Bhayangkara Pembina Keamanan dan Ketertiban Masyarakat or Police's Security and Public Order Officer which hereinafter would be referred to as BHABINKAMTIBMAS, is a member of the Indonesian National Police (POLRI) that is assigned with fostering public security and order (Kamtibmas) and is also in charge of Community Policing (Polmas) in villages/sub-districts.

In this case, the form of effort referred to the roles, functions, tasks of a nation's components and their actual implementation. The National Police of the Republic of Indonesia is part of the efforts of the Indonesian nation to achieve national goals, where this will be carried out properly by involving all components of the nation that are part of the implementation of Maintenance of Security and Public Order (HARKAMTIBMAS). Thus the POLRI, in this case Bhabinkamtibmas, as the leader in creating Harkamtibmas in the village/ sub-district can carry out their duties by applying the community empowerment as an effective way to involve the community in achieving all goals and hopes of creating a safe and orderly situation where they are being assigned. This had been stated in the Regulation of the Chief of the Indonesian National Police Number 3 of 2015 article 27 that the main task of Bhabinkamtibmas is to conduct community development, early detection, and mediation/negotiation in order to create conducive conditions in the village/sub-district. In regards of community policing in Article 1 Paragraph 2, the community policing hereinafter abbreviated as Polmas, is an activity to invite the public through a partnership between members of the National Police and the community, so that they are able to detect and identify problems of security and public order (Kamtibmas) in their environment and resolve them.

According to the explanation above, the existence of Bhabinkamtibmas in the village/subdistrict environment should help solve social problems that exist in the community and minimize all forms of social security disturbances by involving all components of the nation including the community itself. As a police apparatus, Bhabinkamtibmas is the implementer of community policing which through the Police or Bhabinkamtibmas movement is in the scope of maintaining security and order and building police partnerships with the community, so that they can jointly solve problems in the target area that uphold applicable laws and noble values in Indonesian, for the sake of creating peace in society, social justice and social welfare.

Thus, according to the results of a preliminary survey conducted by the researchers, there are still many social and social security disturbances in several sub-districts in East Banjarmasin District, Banjarmasin City, such as an increase in the number of criminal offenses in various places, theft, a group of teenagers who frequently do illegal races on the highway, disrupting traffic order and endangering others. This can be seen that Harkamtibmas does not involve community empowerment as a joint effort, so it appears that dealing with disturbances of social security and Harkamtibmas is solely the responsibility of the Police, Sub-district, and Babinsa officers, despite the fact that it is

very clearly illustrated in the explanations of the various sources above that creating and maintaining International Journal of Politic, Public Policy and Environment Issues, Vol.1, No.1, April 2021 
Kamtibmas involves all components of the nation. Through the role of Bhabinkamtibmas in East Banjarmasin District, Banjarmasin City, the researchers realize the importance of community empowerment in creating and maintaining Kamtibmas. In response to this issue, the goals of this research are to describe the role of Bhabinkamtibmas in the context of community empowerment in East Banjarmasin District, Banjarmasin City, and to identify the factors that become impediments to the role of Bhabinkamtibmas in the framework of community empowerment in East Banjarmasin District, Banjarmasin City.

\section{METHODOLOGY}

The qualitative research approach used in the study is based on the authors' consideration that the approach is relevant in understanding, a phenomenon that occurs in the instrument of collecting data by doing observation, interviews, and documentation about the issue of empowerment Bhabinkamtibmas in order to empower the community in his target village is in use. This is a descriptive study that seeks to provide an overview of the state of the object or problems to be studied based on facts that appear. A survey that examines the issues that concern the object of study in depth is referred to as basic research.

This study was carried out in the city of Banjarmasin, with the research taking place in the East Banjarmasin District. This is done because, based on the discussion with the Head of the Binmas Police in Banjarmasin, it can be used as a reference in relation to this research, taking into account the condition of the village and the ability of BHABINKAMTIBMAS as the object of this research. Sources of data include primary data obtained directly from SCARA in the field and secondary data obtained from materials literature such as documents and reports that relate to the discussion of research this. The author obtained the data from the East Banjamasin Polsek, Banjarmasin Police, village officials, Babinsa, RT/community leaders, and Polri officials who have special duties as Bhabinkamtibmas supervisors beginning at the level of the Regional Police of the South Kalimantan Regional Police and the Banjarmasin Police and Community Servants. The interviewed informants come from a variety of backgrounds, but the majority have the same expertise in the field of Community and Community Protection, so the researcher chooses these informants to provide better information on this research and the presence of different informants to form variations in research subjects. It is hoped that by varying the method, researchers will be able to obtain more diverse data, which will help to enrich the data material in this study.

According to Miles and Huberman (2014), research informants went through the interview stage and the data reduction process, where the results of the interview are described according to the topic, and the focus of this research is the role of Bhabinkamtibmas in community empowerment, which includes community guidance in order to increase community participation in the village / subdistrict.

\section{FINDINGS AND DISCUSSION}

Bhabinkamtibmas has empowered the community to achieve the goals of its role as Bhabinkamtibmas through activities that have been stated in the activity plan, which is determined in a work assignment from the upper unit, and is then implemented and adjusted to the conditions and situations that develop in the District community. East Banjarmasin as an effort to increase the community's capacity, both individually and in groups, in solving various problems that arise in the community's daily life, in this case with the main goal of creating security and public order through the role of Bhabinkamtibmas in carrying out daily tasks that have been carried out. The role of Bhabinkamtibmas is as follows, as stipulated in the Perkap and implementation guidelines in the National Police Ditbinmas (2011) Baharkam Book: 
a. Community guidance for the realization of legal awareness and community service, as well as increasing community participation in the village / sub-district;

b. Protectors and community servants for the realization of a sense of security and peace in the village/sub-district community;

c. Mediators and facilitators in resolving social problems that arise in the village/sub-district community.

\subsection{Community guidance in the context of Community Empowerment for the realization of} legal awareness and community service, as well as increasing community participation

BHABINKAMTIBMAS provides guidance to the community through several mentoring-type activities in order to create a social security situation in its area of responsibility, namely:

1. DDS (door to door system), which entails making visits to the community based on an activity plan created in accordance with the community's situation / development trend in terms of security, social, cultural, economic, ideological, and political issues. In this case, Bhabinkamtibmas has made community empowerment efforts by making visits to the community that have been determined through an activity plan that has been made in accordance with the situation / development trend that occurs in the community, such as socializing community compliance with the Covid 19 health protocol by inviting people who are visited to use masks, keep their distance, and wash their hands and encourage people to not carry out activities that gather large numbers of people without complying with health protocols, for example, wedding receptions, aqiqah (an Islamic ceremony where people make an offering to God by sacrificing goat or cow or chicken), social gathering and so on. Furthermore, Bhabinkamtibmas invites the community to participate in implementing pam swakarsa, which entails fostering and guiding the community to make security efforts in their respective environments by holding a security unit (security guard) independently and forming an Environmental Security Unit (Satkamling) by empowering the existing community's potential. in order to create a sense of security in their respective environment in order to create a conducive atmosphere in which routine community activities can be carried out without worrying about the security in their environment

2. Problem Solving / Problem Solving, namely Bhabinkamtibmas in its duties must be able to provide solutions to problems that occur in people's lives, particularly those related to Community Security, where these efforts create an opportunity for Bhabinkamtibmas to provide guidance to the community regarding the solutions given regarding the problems faced by society so that the community can empow This can be done by Bhabinkamtibmas as an effort to empower the community to solve their problems by empowering the potential they have and Bhabinkamtibmas and the three pillars as a guide / supervisor and encouragement for community participation in its implementation, as in the formation of the Community Awareness Group (Pokdar). Kamtibmas) that can be used as a forum for the community to carry out Kamtibmas problem resolution and legal awareness that occurs.

3. 3. Community Service, which refers to Bhabinkamtibmas' efforts to serve all community needs related to Harkamtibmas affairs that exist in society, as well as individual / individual interests such as the need to administer SIM, STNK, SKCK, and others. In this case, Bhabinkamtibmas' efforts in its role of empowering the community in this regard by providing guidance and direction on how to make a SIM, STNK, SKCK, criminal case settlement, and other Polri services. Whereas in this case, a person / citizen can do it themselves without relying on other people / third parties / brokers / brokers who will incur 
additional costs and the process is not always correct. So that members of the community can do this independently while being guided and, if necessary, accompanied by Bhabinkamtibmas.

4. 4. Community as a Source of Information, specifically the efforts made by Bhabinkamtibmas to guide and encourage community participation in reporting all disturbances of kamtibmas that are either found by themselves, information from other people that can be trusted or is something that many people already know, provide input and suggestions on an information or activity carried out in the community In this case, Bhabinkamtibmas acts as a guide and motivator so that the public can participate in providing good and accurate information to Bhabinkamtibmas and other officials about legal violations in the community or the existence of suggestions and input for the creation of Harkamtibmas. So it is hoped that the creation of a conducive Harkamtibmas can be carried out by empowering the community both individually and group.

5. Government Programs

a. Assistance for Village / Sub-district Funds, namely, the role of Bhabinkamtibmas here is limited to assisting in the guidance, oversight, and supervision of the use of these funds as agreed in the Village Council (Dewan Kelurahan) meeting and applicable regulations.

b. Drug Prevention, specifically Bhabinkamtibmas efforts to develop, guide, and encourage community participation in conducting drug prevention efforts independently, both individually and in groups, as manifested in the formation of community awareness groups or others engaged in preventing drug use, distribution, and production.

c. Socialization of Cyber Crimes (Cyber), namely efforts carried out by Bhabinkamtibmas through mentoring activities (dialogical, counseling, appeals, and information) related to the efforts that the community must make to deal with cyber crimes that have recently occurred, such as fraud via SMS, hacker no. handphone / Whatsapp / E-mail, and so on, which is a crime using technology today.

d. Deradicalization is an effort by Bhabinkamtibmas to reduce radical activities and neutralize radicalism for terrorists and their sympathizers, as well as members of the public who have been exposed to radical terrorist views; this can occur anywhere in Indonesia.

6. Disaster Mitigation

a. Disaster prevention refers to Bhabinkamtibmas' efforts to anticipate disasters, both natural and caused by human behavior, as well as social and health disasters, and so on. In this case, Bhabinkamtibmas collaborates with three pillars and related agencies, as well as top units, to carry out guidance efforts in the form of counseling and information, as well as appeals to the community to anticipate and overcome the aforementioned disasters.

b. Hot Spot is a mapping effort by Bhabinkamtibmas of its task area, namely East Banjarmasin District, regarding disasters that have occurred such as floods, fires, the spread of Covid 19, and so on, which are then used as guidelines in carrying out activities of guidance, counseling, information, and appeal both individually and in groups as the target.

c. Disaster Management, namely Bhabinkamtibmas' efforts in carrying out disaster management in its task area by empowering the existing community potential and 
increasing community capacity (community empowerment) to deal with disasters faced by the community, namely carrying out guidance and training on the potential of the existing community by involving three pillars and parties. -related parties, such as disaster management of house fires by empowering the BPK (fire department) in East Banjarmasin District. Flood Prevention, which in January to February 2020 carried out evacuations by BPK assisted by the National Police (Polres and Polda) and other related parties made flood disaster posts and provided assistance to flood victims and carried out efforts to normalize rivers along A. Yani road, Veterans and other small rivers that have been silting up, reducing river flow and even closing river water flow, where this is done in a synergy between all the authorities and is related to promoting dialogue and demolition which nota bene also empowers the potential of the community around as well as parties who are the target of demolition of bridge buildings or other properties.

7. Bimmas Pioner is an effort made by Bhabinkamtibmas through activities to improve community welfare which is carried out based on the potential in its area of work by utilizing community self-help, where these activities can be in the form of cultural, economic, agricultural or plantation activities, livestock or fisheries and so on, In this case, Bhabinkamtibmas plays a role as an encouragement for community participation in carrying out the projects they agree on, as well as as a guide and mediator for problems faced by the community in implementing the program/project. Regarding this, the informant's statement tells that:

"What Bhabinkamtibmas Sub-district can do is making efforts to carry out food security by becoming a pioneer in making catfish/tilapia rearing in large drums/barrels/buckets as well as a container for planting kale vegetables, although in fact not many community members have participated in it" (interview with informant dated August 7, 2020).

According to the above explanation, Bhabinkamtibmas' efforts in its role as a guide and encouragement for community participation in community empowerment occurred when Bhabinkamtibmas carried out its activities related to DDS, Problem Solving, Community Service Pioneers, Disaster Prevention, and Manage This can be seen in Bhabinkamtibmas' efforts to carry out the aforementioned activities with the goal of creating a good social and security situation, with the main target at the time of this research being the community's ability to face the spread of the Covid 19 Pandemic and public anticipation of rampant incidents of crime and the circulation of Narcotics by forming a Conscious Group Kamtibma.

This is evidenced by the establishment of Kampung Tangguh Banua on Jalan Manggis Gg Mangga Rt 32 Kebun Bunga Village to anticipate the Covid 19 pandemic and its consequences, as well as various parties holding Swakarsa security (security guards and security guards) in housing / settlements, offices / companies, private homes, and certain places that become the center of the crowd, such as hotels, plazas / malls. The affected area is Kebun Bunga Village, and all of these efforts are supported by the government, Polri, and TNI, as well as other related parties, to create a social security situation conducive to achieving a better life and development. According to Prijono's community empowerment theory, community empowerment is an effort to create or increase the capacity of the community, both individually and in groups, in solving various problems related to efforts to improve the quality of life, independence, and welfare (Prijono, 2001: 245). 


\subsection{Mediators and Facilitators in solving social problems that occur in the community}

The role of Bhabinkamtibmas as a Mediator and Facilitator in solving social problems that occur in the people of East Banjarmasin District, Banjarmasin City is carried out as an effort by Bhabinkamtibmas as the strike force of the National Police organization to anticipate and solve problems that are still simple and can be solved through the first steps,

Bhabinkamtibmas can realize its role as a Mediator and Facilitator in resolving social problems that affect the people of East Banjarmasin District, Banjarmasin City, through activities such as:

1. DDS (door to door system) is expected to be able to find and know social problems that occur and actually, so as to provide directions and directions to the community, as well as to mediate and facilitate solutions, by visiting the community every day door to door. These issues arise as a result of their authority and role as Bhabinkamtibmas and members of the Three Pillars, which provide a sense of security, serenity, and peace, as well as a deterrent effect on society in order to create a safe, orderly, peaceful, and prosperous life. This is evident in the problem of dealing with Covid 19, which has recently become a humanitarian disaster all over the world, including Indonesia. In this case, Bhabinkamtibmas collaborates/partners with the Lurah and Babinsa (Three Pillars) to carry out coaching activities and driving behavior change, as well as mediators and facilitators for the implementation of Covid 19 prevention and handling by the local community. Tangguh Banua Village, located on the mangosteen road, Kebun Bunga Village, which is currently being developed by the National Covid 19 Handling Task Force, which is driven by the BPBN (National Disaster Management Agency)./Sub-district Tangguh Covid 19, consisting of the Tangguh Covid 19 Command Post in every RT/RW in the villa. This is in accordance with the Ministry of Home Affairs Instruction Number 1 of 2020, dated 18 September 2020, regarding the prevention of the spread of Covid 19, as well as the Minister of Home Affairs Circular Number 440/5184/SJ, dated 17 September 2020, regarding the establishment of the Covid 19 Handling Task Force in the regions.

2. Bhabinkamtibmas, in its role as Mediator and Facilitator in solving social problems that occur in the community of East Banjarmasin District, Banjarmasin City, resolves problems that occur in society. When solving these problems requires the participation of other parties, Bhabinkamtibmas will carry out its role to mediate and facilitate the community in finding solutions to these problems. terms of solving this flood problem, it requires efforts made by agencies/institutions/organizations that are higher than sub-districts and even sub-districts as well as across agencies/institutions/organizations. So the role of Bhabinkamtibmas and the other three pillars is very much needed to mediate and facilitate it for the handling of the flood disaster. This can finally be done through the role of each of the three pillars in coordination with the units/agencies/institutions/organizations above, such as Polsek/Subdistrict/Koramil even at the Police/Municipal/Kodim Level and specifically for the Police. In this case, the South Kalimantan Regional Police are also involved. Directly in the handling of this flood disaster by assigning the Director of Community Development of the South Kalimantan Regional Police as the Coordinator of Flood Disaster Management in the City of Banjarmasin to assist the Banjarmasin Police, in order to make efforts including handling evacuation and displacement of people affected by flooding, coordinating and distributing Clothing/Food Aid to victims affected by flooding, as well as efforts to deal with the sources of flooding caused by community violations related to river water flow in Banjarmasin City and its surroundings so that it is in the form of a River Normalization Task 
Force for Flood Control in Banjarmasin City in accordance with Governor's Decree Number 77 Year 2021.

3. Community Service that Bhabinkamtibmas in its role as a Mediator and Facilitator in solving social problems that occur in the community of East Banjarmasin District, Banjarmasin City carries out community service activities that require Bhabinkamtibmas assistance related to community interests related to the main duties and functions of the National Police, such as making SIM, STNK, BPKB , SKCK and so on which are individual in nature, but if it related to community empowerment such as the formation of Community and Community Protection Groups (PokdarKamtibmas), the formation and establishment of the Tangguh Banua Village (KTB) in the response to Covid 19, the Establishment of a Security Unit (Satpam) and an Environmental Security Unit (Satkamling), where all of these are community empowerment efforts carried out independently which must be served by Bhabinkamtibmas in order to guide, direct, supervise and others to achieve the goals desired by the community.

4. Community Pioneering Development (Binmas Pioner or Binmas The Pioneer Officer) that in the role of Bhabinkamtibmas as Mediator and Facilitator in solving social problems that occur in the community of East Banjarmasin District, Banjarmasin City is a pioneer of activities that are beneficial to the community to solve social problems that occur. occurs in people's lives such as the handling of Covid 19 and the Flood Disaster that occurred in January 2021. Bhabinkamtibmas as the Pioneer in this case as the Mediator and Facilitator provided assistance in the form of forming a strong post for handling flood disasters in several RT / RW affected by floods and together with the three pillars make efforts to provide basic food assistance and clothing needs by becoming a facilitator for agencies / institutions and community organizations to channel assistance to flood-affected communities in the East Banjarmasin District area, as well as being a mediator between the government, in this case the river normalization task force formed by the Mayor of Banjarmasin with residents whose houses, bridges and so on were targeted for demolition because they became obstacles to the flow of river water and some violated house construction rules and others. Where according to the applicable regulations, demolition must be carried out immediately, but due to humanitarian considerations, it is mediated by Bhabinkamtibmas and three other pillars so that a solution is agreed, in order to support each other's efforts to normalize the river.

\subsection{Dimicators and motivators of positive community activities in the context of creating and maintaining kamtibmas}

Bhabinkamtibmas in terms of carrying out its role as a dynamist and motivator for positive community activities in order to create and maintain community service in East Banjarmasin District, Banjarmasin City seeks to carry out community development activities that motivate the community and dynamize community activities through community empowerment to create a safe, orderly and peaceful situation., so that the existing community can carry out their daily activities safely and peacefully and without any sense of anxiety about the safety of themselves and their assets and free from physical and psychological disturbances.

In this case, Bhabinkamtibmas realizes it through activities, including the following:

1. DDS (Door to Door System) by visiting the community as determined in the activity plan such as the Head of the Village, Community / Religious / Youth Leaders, Head of Office / Head of Company / Housing, Head of RT / RW and so on in order to discussing / discussing efforts to encourage the formation of Pam Swakarsa according to Police Regulation Number 
04 of 2020 concerning Self-Protection (Security Unit (Satpam) and Environmental Security Unit (Satkamling)) which is an effort to create and maintain Community Security and Order in their respective environments. is in the district of East Banjarmasin. Where for now it is developing according to the existing situation, namely the response to Covid 19 to become a Tangguh Village / Sub-District at the Sub-district level and the Covid-19 Tangguh Command Post in the existing RT / RW as Instruction of the Minister of Home Affairs and Circular of the Minister of Home Affairs regarding the formation of Tangguh Village and Tangguh Covid 19 Post and more further related to the implementation of PPKM-BM (Enforcement of Micro-Scale Community Activity Limits).

2. Problem Solving / Problem Solving, namely that in carrying out its role as a dynamist and motivator for Bhabinkamtibmas, it also often faces community problems that occur in shaping and fostering communities related to the creation and maintenance of Community Security and Order in East Banjarmasin District.

Problems that often arise in this case are constraints on the procurement of space and personnel as well as operational completeness of an activity such as the establishment of a Security Unit, Environmental Security Unit, Tangguh Village / Sub-District and Tangguh Covid 19 Post, so that with Bhabinkamtibmas it can provide direction and motivate the community for its formation and to dynamize its activities so that community activities related to security units / task forces to posts that have been formed can be maximized so as to achieve the expected goals. This is inseparable from the efforts of Bhabinkamtibmas to empower existing community resources with the help of the government in synergy to revive and carry out the operations of the units that have been in the form mentioned above.

3. Community Service that in its role as a dynamist and motivator for positive community activities in order to create and maintain community service in East Banjarmasin District, Banjarmasin City, Bhabinkamtibmas carries out service activities to the community related to community demands and needs in carrying out its activities for the creation and maintenance of community security and order either individually or in units / groups such as services for making KTA (Membership Card) of the Security Unit (Satpam), as a resource person in the guidance of the Security Unit carried out by companies/agencies and/or Subdistrict in guiding community members related to the development of the Environmental Security Unit. This community service can also be in the form of assisting the Sub-district government to socialize and motivate and dynamize the community for the implementation of the creation and maintenance of Community Security and Order in the form of mobile counseling using the equipment and infrastructure they have.

4. Innovation, namely that Bhabinkamtibmas in carrying out its duties must be able to make innovations in fostering and guiding the community related to maintaining security and public order in the village / sub-district under its guidance, even though sometimes the innovations made are instructions received from the upper units that have been determined or it has been programmed, but this is something new in the village / sub-district community it fostered. Acting as a dynamist and motivator, Bhabinkamtibmas must be able to motivate and dynamize the community to be able to make reforms for what he thinks is not in accordance with existing developments so that these reforms must be carried out. As is what Bhabinkamtibmas has done with the existing security systems in several offices / companies, from the security pattern of the Satkamling (Environmental Security unit) being updated to the security pattern of the Security Unit by updating personnel, security infrastructure, officer clothes / uniforms and organizational structure. security unit at the office / company. 
Where this is done with non-governmental organizations / offices / companies by empowering the potential they have.

5. The Report of Kamtibmas Disturbances that Bhabinkamtibmas which carries out its role as a dynamist and motivator of positive community activities in order to create and maintain security and security in East Banjarmasin District, Banjarmasin City must be able to motivate and dynamize the community both individually and in groups to be willing to report all existing social security disturbances. whether it is found by yourself, information from other people who can be trusted or is something that is already known by many people to Bhabinkamtibmas and the closest police unit, and or the Lurah or Babinsa as partners in the three pillars. Such as the unpleasant treatment, disturbing the general peace of the community by a group of thugs who always carry out activities that are criminal in nature, such as bullying, drunkenness and commotion so as to disturb public order, peace and peace, so this must be reported so that Bhabinkamtibmas / Polri can take police action based on reports that have been done officially, so that law enforcement can be done properly and correctly.

6. The community as a source of information that Bhabinkamtibmas in its role as a dynamist and motivator of positive community activities in order to create and maintain kamtibmas in East Banjarmasin District, Banjarmasin City, must be able to motivate and dynamize people's thinking as a source of information on various problems and input, suggestions and opinions both in oral form and data that are accurate and can be accounted for so that they can be used as material for consideration for Bhabinkamtibmas and Polri units at the executive level and at the Polri unit at the level of policy makers in making decisions. We can see this in the policies of the police leadership towards handling the handling of covid 19 that are currently happening by making efforts to form a National Resilient Village (KTN), Community Awareness Group (Pokdarkamtibmas) and so on, which are policies taken based on input from the community received through Bhabinkamtibmas and continues to the units above until it is used as input for making decisions about its implementation. At the village / sub-district level, information input from the community can be taken into consideration in the implementation of the operational implementation of the National Tangguh Village or Tangguh Banua Village (KTB) which is carried out based on the consideration of existing local wisdom, for example the enforcement of justice against violators of the implementation of Covid 19 countermeasures that have already been implemented. made in the form of regional regulations, but in practice it is adjusted to the existing situation in each region.

7. Government programs consisting of Village Fund Assistance, Combating Shackling, Drug Prevention, MR Vaccine Socialization, Cyber Crime Socialization, Deradicalization that Bhabinkamtibmas in its role as a dynamist and motivator of positive community activities in order to create and maintain community service in Banjarmasin Timur Kota District Banjarmasin must be able to motivate and dynamize the community towards the government programs mentioned above in order to carry out the success of these programs which can be done with community empowerment efforts, as well as collaborating with stakeholders and other stakeholders. An example of one of the government programs mentioned above is the prevention of drugs, with the ability to motivate and dynamize the people of the Sub-district to form a Community Awareness Group (Pokdarkamtibmas) so that they can make efforts by the community to prevent the spread / distribution and use of drugs in the community in general, especially the younger generation, by holding regular meetings containing counseling on drug prevention and the delivery of information about whether or not people 
are involved with the distribution and use of drugs. In line with the informant's statement, namely that:

8. Disaster Mitigation which consists of Disaster Prevention, Hot Spot, Disaster Management that Bhabinkamtibmas in its role as a dynamist and motivator of positive community activities in order to create and maintain kamtibmas in East Banjarmasin District, Banjarmasin City must be able to motivate and dynamize the community towards efforts. community empowerment efforts in disaster mitigation include disaster prevention, hot spots, disaster management. In this case, Bhabinkamtibmas carries out coaching, counseling and information activities for the community with the aim of making the community a resource in dealing with disasters that occur in its area of duty, in this case according to the facts that are often experienced in the area. Examples of a House Fire Disaster which is a disaster that is often experienced by the community so that efforts are made by the community to anticipate and prevent fires as well as provide counseling and information about the climate situation and things that must be done to avoid fires, as well as efforts to overcome against the fire that occurred by setting up the BPK (Fire Service Agency) in 5 (five) RTs in East Banjarmasin District.

9. Community Development Pioneers (Binmas Pioner or Binmas Officer The Pioneer) that Bhabinkamtibmas in its role as a dynamist and motivator of positive community activities in order to create and maintain kamtibmas in East Banjarmasin District, Banjarmasin City must be able to motivate and dynamize society towards community activities that make society as a resource (community empowerment) to make efforts to increase the capacity of the community in the field of Food and Clothing, facilities and infrastructure, especially in the field of Community and Community Protection in order to achieve a safe, peaceful and prosperous community life.

\subsection{Factors that become Constraints on the Role of BHABINKAMTIBMAS in the Framework of Community Empowerment}

The role of Bhabinkamtibmas, which is carried out by Bhabinkamtibmas personnel in the Village/ Subdistrict area, which is their duty zspace, cannot automatically be carried out without any obstacles/ obstacles as happened to Bhabinkamtibmas who carry out their duties in East Banjarmasin District, Banjarmasin City. This can be explained based on the findings in the field and the results of interviews conducted by researchers with informants as well as from the supporting documents found.

Obstacles / Constraints in the role of Bhabinkamtibmas obtained from the results of this study are divided into Internal and External Factors with the following explanation:

1. Constraints from Internal factors:

a. The number of personnel is insufficient.

With the number of Bhabinkamtibmas personnel who are alone / one Bhabinkamtibmas in one Village / Sub-district, it is felt that they are still very lacking when compared to the area, population and task load given, so that sometimes Bhabinkamtibmas has to carry out tasks beyond working hours even at the same time. Able to carry out several tasks that are their responsibility and the demands of the leadership and upper units, so that this greatly affects the quantity and quality of work results and the achievement in its role as Bhabinkamtibmas in the context of community empowerment. When this happens, a Bhabinkamtibmas must be able to coordinate with related parties and be able to empower elements in society related to the activities they carry out. 
b. Insufficient Budget

Babinkamtibmas in carrying out its role is often constrained in carrying out its activities because of the minimal operational budget, when compared to the burden of tasks / activities that must be carried out by Bhabinkamtibmas. So that this will also greatly affect the daily activities of Bhabinkamtibmas as the executor of the role in community empowerment, which in this writing is the focus of discussion.

c. Personnel has double duty.

The fact that was found in the field that Bhabinkamtibmas in carrying out its role was also constrained by the existence of other positions given to the person concerned because of the lack of the number of personnel available so that in carrying out daily duties Bhabinkamtibmas must be able to share time and ability in carrying out its role as Bhabinkamtibmas and as members / executors of other police duties, such as Sabhara, Reskrim, Intel and so on.

d. The knowledge and ability of the press regarding community empowerment and technology is not yet maximal.

Bhabinkamtibmas as the subject in its role of implementing conceptual community empowerment is found to have not understood what and how community empowerment is so that in its implementation it only relies on its own approach capabilities, this makes the implementation of community empowerment which should be used as a sufficiently good resource in order to achieve maximum results. in comparison to the current various kinds of activities cannot be done. In addition, the ability of Bhabinkamtibmas to develop technology is still not optimal when compared to the existing urban community capabilities, so that existing community empowerment efforts still have many obstacles such as the ability to create an online communication network if needed to coordinate with stakeholders. interests and three pillars as well as community leaders so that in its implementation in the conditions of the Covid 19 pandemic this cannot be done because of limitations regulated in the health protocol in dealing with Covid 19.

\section{Constraints from external factors:}

a. The attitude of society that tends to be Individualistic/apathies.

The condition of the people of East Banjarmasin District who are in urban areas and have jobs that are more competitive in nature and take advantage of a long time, so that it greatly affects their attitudes and behavior which are seen in general tend to prioritize personal interests and less concerned about common interests, especially related to community empowerment. This is due to the many individualistic interests that every citizen has in connection with the fulfillment of their primary and secondary needs, even the demands of luxury goods, which in their view must be fulfilled by them and cannot expect from others. This is one of the obstacles to the implementation of community empowerment so that Bhabinkamtibmas must be able to play a role as an instructor, advocate and be able to influence the community to understand that community empowerment to create Harkamtibmas in its area is a need that needs to be developed jointly through the Polmas (Polmas) program. Public ).

b. Prejudice against new things.

There are past experiences that have been done by government agencies / institutions and it only seems ceremonial which makes people think that what will be done now is just meeting the achievement targets for implementing the community empowerment, so that 
Bhabinkamtibmas in carrying out its role as program implementer in The creation of Harkamtibmas in East Banjarmasin District faces attitudes and behaviors that seem a priori and / or suspicious of the programs / activities carried out by Bhabinkamtibmas in order to achieve the desired expectations by empowering the community. In this case, Bhabinkamtibmas in carrying out its role faces the challenges of several individuals who do not support its activities, for example the formation and implementation of self-initiated pam in the form of a security guard or security guard.

c. Feeling insecure (self-distrust)

Insecurity makes a person unsure of his abilities so that it is difficult to explore and bring out the potential that is in him. This makes it difficult for people to develop because they don't want to develop according to their potential. This situation is encountered in the community of East Banjarmasin Subdistrict, where there are a few people who prefer not to participate in any activities carried out by village officials. This is a challenge for Bhabinkamtibmas which carries out its role in community empowerment with the Subdistrict government to change the way of thinking and self-confidence of its citizens so that they can accept the efforts made through government programs and the National Police program which are expected to increase their welfare.

d. Dependency

Dependence on something or someone in society, especially related to community empowerment programs carried out by Bhabinkamtibmas in maintaining security and public order, greatly affects the achievement of the results of these activities. This is a challenge for Bhabinkamtibmas for how to make the community understand quickly and be able to carry out Harkamtibmas activities and other government programs independently by empowering the potential of the existing community without having to depend on government officials, so that they will be able to achieve the formation of community life on their own. who are prosperous and independent.

e. Interest Group.

Community empowerment in its implementation cannot be carried out properly because of the existence of an interest group that can be one of the obstacles in efforts to empower the community. For example, efforts to empower the community in implementing the Covid 19 health protocol in an area including those that are nota bene is an area of the city of Banjarmasin which has quite a lot of shops, markets and stalls as well as entertainment venues so that at first they tried to make the Covid 19 Health Protocol extension especially related to limiting people in crowding not to be done massively but it can be carried out based on their interests because it will have an impact on their business / business / work interests. So that this hinders efforts to contain the massive and precise spread of the Covid 19 virus. This is a challenge for Bhabinkamtibmas in carrying out its role to create a good understanding of overcoming the spread of the Covid 19 virus, more importantly when compared to the losses they have experienced and become a material for their consideration in running their business / business / work, even if necessary efforts are made to make them comply with government programs related to the response to covid 19.

\section{CONCLUSION}

Bhabinkamtibmas in the context of community empowerment can be carried out through the role of Bhabinkamtibmas. However, it is still not optimal because many programs or activities carried 
out in community empowerment by Bhabinkamtibmas are limited to fulfilling assigned tasks. Community empowerment that is carried out is only limited to how to take advantage of the moment and part of the community's potential in order to achieve the task targets assigned to it, and it has not yet reached how to empower the community optimally by carrying out the role of Bhabinkamtibmas properly and sustainably, through understanding the definition of community empowerment, empowerment. as a process, community empowerment as a goal, stages of empowerment, empowerment strategies and so on, in order to create a society that is ready to be empowered and independent towards the creation of a community and social security situation that is conducive to realizing a safe, peaceful, peaceful society and ensuring the implementation of development towards prosperity.

Inhibiting factors that were felt internally were the number of personnel lacking, insufficient budget, personnel placement were still double jobs, lack of knowledge, understanding and ability of the Bhabinkamtibmas press regarding the concept of community empowerment and technology that was not optimal. Externally, the community's attitude that tends to be individualistic/less concerned, suspicious of new things, reliance on other parties, and group interests. These factors greatly influence the success of Bhabinkamtibmas in carrying out its role.

In this case, it is necessary to make maximum efforts and jointly between the three pillars and stakeholders and other related parties in realizing better community empowerment through increasing the ability of Bhabinkamtibmas itself, then procuring government programs at Sub-district level that can participate in Bhabinkamtibmas activities by maximizing its role.

\section{REFERENCES}

Baharkam Polri Direktorat Binmas, ( 2011 ) Standard Operasional Prosedur Tentang Pelaksanaan Tugas Bhabinkamtibmas Di desa / Kelurahan.

Hamalik Oemar, 2005. Pengembangan Sumber Daya Manusia Manajemen Pelatihan Ketenagakerjaan Pendekatan Terpad. Jakarta :. Bumi Aksara.

Hasibuan S.P. Malayu, 1997, Manajemen Sumber Daya Manusia, Jakarta: Gunung Agung.

Kaho, Josef Riwu, (2002), Prospek Otonomi daerah di Negara Republik Indonesia, Jakarta: Rajawali. Manullang, (1978), Administrasi kepegawaian, Jakarta: Haji masagung.

Musanef, 1996. Manajemen Kepegawaian di Indonesia. Jakarta: Gunung Agung.

Notoatmodjo, sukijo, (1997), Pengembangan Sumber Daya Manusia, Jakarta: Balai Pustaka.

Peraturan Kepala Kepolisian Negara Republik Indonesia Nomor 3 Tahun 2015Tentang Pemolisian Masyarakat.

Peraturan Kepala Kepolisian Nomor 7 Tahun 2008 Tentang Pedoman Dasar Strategi dan Implementasi Pemolisian Masyarakat dalam Penyelenggaraan Tugas Polri.

Siagian, SP., (1996), Manajemen Sumber Daya manusia, Jakarta: Bumi Aksara

Sugiyono ( 2017 ) Metode Penelitian Kuantitatif, Kualitatif dan Kombinasi ( Mixed Methods ), Bandung Alfa Beta.

Surat Keputusan Kapolri Nomor. Pol. : Skep/433/VII/2006 tanggal 1 Juli 2006 tentang Panduan Pembentukan dan Operasionalisasi Polmas.

Surat Keputusan Kapolri Nomor. Pol: Skep/737/X/2005 tanggal 13 Oktober 2005 tentang Kebijakan dan Strategi Penerapan Model Perpolisian Masyarakat dalam Penyelenggaraan Tugas Polri.

Undang-Undang Republik Indonesia Nomor 2 Tahun 2002 Tentang Kepolisian Negara Republik Indonesia.

Undang-Undang Republik Indonesia Nomor 2 Tahun 2002 Tentang Kepolisian Negara Republik Indonesia. Lembaran Negara Republik Indonesia Tahun 2002 Nomor 2. Tambahan Lembaran Negara Republik Indonesia Nomor 4168 